\title{
ANALYSIS OF COST STRUCTURE AND COMPARATIVE INCOME OF OIL PALM AND COCONUT COMMODITIES ON SMALLHOLDER PLANTATIONS IN NORTH ACEH DISTRICT
}

\author{
Mawardati $^{1}$, Jullimursyida ${ }^{2}$, Irada Sinta ${ }^{3}$, Loly Paramita ${ }^{4}$, Gus Razaki $^{5}$ \\ 1,3,4,5 Faculty of Agriculture, Universitas Malikussaleh \\ ${ }^{2}$ Faculty of Economic and Business, Universitas Malikussaleh \\ E-mail: mawardati@unimal.ac.id
}

\begin{abstract}
ABSTRAK
This research was conducted on oil palm and coconut plantation commodities in North Aceh Regency. The purpose of this study is to analyze the cost structure and the comparison of net income in the two businesses. The analytical methods used are cost analysis, net income, and Independent $T$-test analysis. The results of the analysis show that the production cost of oil palm plantations is higher than that of coconut. However, the results of the income analysis show that both businesses provide benefits to farmers and are feasible to work on. Furthermore, based on the results of the Independent T-test analysis shows that there is a significant difference in income/profits in the two businesses. The average income/profit of oil palm plantations is higher than that of coconut plantations due to the productivity and price of coconut being lower than that of oil palm. In addition, generally coconut farmers in the research locations directly market their coconuts after harvesting, and it is very rare for farmers to consider the selling price factor. Unlike the case with oil palm farmers, although the price of fresh fruit bunch fluctuates, it follows the standard price both between farmers and between regions. Oil palm farmers also often receive counseling from various parties, while coconut farmers in the research location have never received any counseling at all.
\end{abstract}

Keywords: Cost, Income, Comparative, Oil Palm, Coconut

\section{INTRODUCTION}

The high demand for the export of plantation products has encouraged the development of various plantation commodities in the country. This is very reasonable considering that almost all plantation commodities have a fairly high export value. In addition, the plantation sub-sector also contributes to meeting the needs of domestic industry raw materials and providing employment opportunities for the majority of Indonesia's population. Minister of Agriculture Syahrul Yasin Limpo (2019) said that plantations are the most promising sub-sector for increasing foreign exchange and improving people's welfare. The development of plantation commodities occurs in almost all parts of Indonesia. Although each region has specific superior commodities due to climatic conditions and local government policies. Although each region has specific superior commodities due to climatic conditions and local government policies.

North Aceh Regency Aceh Province is one of the districts with great potential for the development of plantation commodities. The plantation area based on land use data in North Aceh Regency is 50,201 hectares or 15.83 percent of the area of North Aceh Regency. Among several some many plantation commodities developed in this area, oil palm and coconut are the 2 (two) commodities that occupy the top position in terms of the area cultivated, especially people's plantations (BPS North Aceh Regency, 2020).

On the one hand, the increase in area for these two commodities occurs from year to year. Currently, the area of oil palm is 18,185 hectares and coconut is 14,997 hectares (BPS North Aceh 


\section{ANALYSIS OF COST STRUCTURE AND COMPARATIVE INCOME OF OIL PALM AND COCONUT COMMODITIES ON SMALLHOLDER PLANTATIONS IN NORTH ACEH DISTRICT \\ DOI: https://doi.org/10.54443/ijebas.v2i1.141}

Regency, 2020). On the other hand, the management of these two commodities is also faced with various obstacles, such as the limited processing industry (agro-industry) which causes the selling price of products to fluctuate and tend to below. In addition, the difficulty of farmers accessing capital, the limited ability of farmers to adopt technology so that productivity is low because the management is still traditional. Judging from the aspect of the palm oil processing industry, it already has large and medium-scale agro-industry although it is still limited, while the coconut agro-industry is not only limited in number but also small and medium scale. However, the growth in the area over the last 5 (five) years shows that coconut plantations have grown at a higher rate of 4.17 percent, while oil palm has only grown 2.17 percent (BPS North Aceh Regency, 2020).

In connection with some of these problems, plus the issue of environmental conditions for oil palm commodities, the current policy of the North Aceh Regency government remains to focus on plantation development but is urged to expand the plantation area to choose commodities other than oil palm. Based on the above conditions, the question now is which commodity between oil palm and coconut is a priority to improve welfare in terms of the income level of farmers in North Aceh Regency.

\section{IMPLEMENTATION METHOD}

This research was conducted in North Aceh District using a survey method. The population in this study were oil palm farmers and coconut farmers in North Aceh Regency. The location of the sample was determined purposively in 4 (four) sub-districts which have a larger area for the two commodities than other sub-districts in North Aceh Regency. The sampling technique was carried out using the snowball sampling technique. The total sample in this study was 72 families with details of 40 families of oil palm farmers and 32 families of coconut farmers from 4 selected districts. The data used in this study are primary data and secondary data. Primary data was obtained from the results of filling out a previously prepared questionnaire as a guide for direct interviews with farmers. Secondary data is used to support and complement primary data. Secondary data were obtained from the Central Statistics Agency (BPS), the North Aceh Regency Plantation Service, the sub-district office, and the local Agricultural Field Extension Officer (PPL).

\section{RESULT AND DISCUSSION}

\section{A. Production Costs for Oil Palm Plantation and People's Coconut in North Aceh District}

Tabel 1. Average Production Cost of Palm Oil and Coconut for Smallholders in the Research Locations 2021

\begin{tabular}{|l|r|r|}
\hline \multicolumn{1}{|c|}{ Production cost } & Palm Oil Commodity & Coconut Commodity \\
\hline Production Cost / land area / year & $5.880 .072,00$ & $1.185 .429,00$ \\
Production Cost / hectare/year & $2.079 .538,00$ & $1.488 .201,00$ \\
\hline
\end{tabular}

Table 1 shows that there are differences in the average use of production costs in oil palm and smallholder coconut plantation businesses in North Aceh District. Production costs in smallholder oil palm plantations are higher than production costs for coconut plantations. The high cost of production in oil palm plantations is caused by differences in the costs of gardening and plant maintenance. Most of the oil palm farmers carry out plant care by applying fertilizers and eradicating pests and diseases even though they are not by following per under the recommendations. In addition, oil palm farmers also clean their plantations at least once a year. In contrast to coconut farmers, who rarely take care of both plant maintenance and garden cleaning. At the research site, it was found that 
farmers only plant coconut trees, then wait for harvest and harvest continuously until the plants no longer produce. Coconut farmers rarely carry out plant maintenance such as fertilization, pest, and disease eradication including garden cleaning, only a small number of them do. This condition does not only occur in people's coconut plantations, but also in other agricultural businesses such as Ellyta Effendy et all research (2019) which also found that generally patchouli farmers in Aceh Province also do not fertilize their plants.

B. Net Income/Profits and Analysis of Differences in Net Income/Profits in Oil Palm and Coconut Oil Palm Businesses in North Aceh District

Tabel 2. Average Profits from Palm Oil and Palm Oil Businesses in North Aceh District 2021

\begin{tabular}{|l|r|r|}
\hline \multicolumn{1}{|c|}{ Benefit } & Palm Oil Benefits & Coconut Benefits \\
\hline Profit/land area & $54.031 .997,00$ & 11.396 .237 \\
Profit/hectare & $19.108 .877,00$ & 14.304 .900 \\
\hline
\end{tabular}

Table 2 shows that the average profit from the oil palm business is greater than the average profit from the coconut business on smallholder plantations in North Aceh Regency. In other words, it can be explained that the profits of the people's oil palm plantation business are 33.58 percent higher than the people's coconut plantation business. This can be explained that the high average cost of production used in smallholder oil palm plantations, followed by high production, coupled with the stable selling price of oil palm, causes smallholder oil palm businesses to gain greater profits than smallholder coconut plantations.

The results of the different income/profit tests using the Independent Sample Test show that the value of Sig. Levene's Test for Equality of Variances is $0.02<0.05$. This shows that the data variance between the average net income/profits of oil palm and coconut on smallholder plantations is not the same or not homogeneous (V. Wiratna Sujarweni, 2014). Therefore, furthermore, it must be guided by the values contained in the Equal variances are not assumed table in the Independent Samples Test output. The output results in the equal Variances are not assumed column show the sig value. (2-tailed) of $0.04<0.05$. Thus, it can be concluded that there is a significant difference between the average net income of smallholder oil palm and coconut plantations in North Aceh District, Aceh Province. In line with these findings (Sukamto, 2001) said that the coconut plantation business in Indonesia is rather difficult to develop because it competes with oil palm. Mawardati, et al (2021) research concludes that the profits from coconut plantations are also lower than those of areca nut plantations on smallholder plantations in North Aceh Regency. Coconut plantations in Indonesia are dominated by smallholder plantations whose management is still traditional.

\section{CONCLUSION}

Based on the analysis of the research conducted, it can be concluded that the results of the analysis show that plantation production costs for oil palm commodities are higher than for coconut commodities. However, the results of the income analysis of the two businesses provide benefits to farmers and are feasible to work on. There is a significant difference in net income/profit between oil palm and coconut commodities on smallholder plantations in North Aceh Regency. The average net income/profit of oil palm plantations is higher than that of coconut plantations due to the productivity and price of coconut being lower than oil palm. In addition, coconut farmers never receive counseling and rarely do garden maintenance so the amount of product produced is also low. 
ANALYSIS OF COST STRUCTURE AND COMPARATIVE INCOME OF OIL PALM AND COCONUT COMMODITIES ON SMALLHOLDER PLANTATIONS IN NORTH ACEH DISTRICT

DOI: $\underline{\text { https://doi.org/10.54443/ijebas.v2i1.141 }}$

\section{ACKNOWLEDGMENTS}

This research was conducted with financial support from Non-Tax State Revenue (PNBP) in the Malikussaleh University Budget Implementation List (DIPA) for the 2020 Fiscal Year the with contract number: 109/PPK-2/SPK-JL/2021 facilitated by LPPM Malikussaleh.

\section{REFERENCES}

BPS, 2020. Luas Areal Tanaman Perkebunan Rakyat Menurut Jenis Tanaman. https://www.bps.go.id/indicator/54/770/1/luas-areal-tanaman-perkebunan-rakyat-menurutjenis-tanaman.html

BPS. Aceh Utara Dalam Angka, 2020. Biro Pusat Statistik Kabupaten Aceh Utara.

Effendy. E, dkk, 2020. Keragaan Kelembagaan Pertanian dan Model Pengembangan Agribisnis Nilam Aceh. Jurnal Ekonomi Pertanian dan Agribisnis (JEPA) Volume 4, Nomor 4, HAL : 728-737. https://jepa.ub.ac.id/index.php/jepa/article/view/483 (diakses 1 Desember 2020)

Mahmud Z, 2008 . Modernisasi Usahatani Kelapa Rakyat. Pengembangan Inovasi Pertanian. Vol. 1 No. 4.

Mawardati dkk, 2021. Comparative Benefits of People's Plantation Business in North Aceh District. International Journal of Advances in Engineering and Management. Volume 3, Issue 5 May 2021, pp: 441-445

Nafarin, M. 2009. Penganggaran Perusahaan,Jakarta : Salemba Empat.

Sujarweni, V. Wiratna. 2014. Metode Penelitian: Lengkap, Praktis, dan Mudah Dipahami. Yogyakarta: Pustaka Baru Press.

Sukamto, 2001. Upaya meningkatkan produksi kelapa. PT. Penebar Swadaya. Jakarta.

Syahrul Yasin Limpo, 2019. Sektor Perkebunan Andalan Devisa dan Kesejahteraan Petani. Warta Ekonomi. https://www.wartaekonomi.co.id/read254999/sektor-perkebunan-andalan-devisadan-kesejahteraan-petani (diakses 5 Juli 2020). 